\title{
Palynological evidence of the replacement of the hygrophilous forest by field vegetation during the last 7,000 years B.P. in the northern coast of Rio de Janeiro, Brazil
}

\author{
CYNTHIA F.P. DA LUZ ${ }^{1,2}$, ORTRUD M. BARTH ${ }^{2,3}$, LOUIS MARTIN ${ }^{4}$, \\ CLEVERSON G. SILVA ${ }^{5}$ and BRUNO J. TURCQ ${ }^{4}$ \\ ${ }^{1}$ Instituto de Botânica, Núcleo de Pesquisa em Palinologia, Avenida Miguel Stéfano 3687, 04301-902 São Paulo, SP, Brasil \\ ${ }^{2}$ Universidade Federal do Rio de Janeiro, Instituto de Geociências, Departamento de Geologia, \\ Laboratório de Palinologia, CCMN, J2-19, Ilha do Fundão, 21949-900 Rio de Janeiro, RJ, Brasil \\ ${ }^{3}$ Fundação Oswaldo Cruz, Departamento de Virologia, Laboratório de Ultra-estrutura Viral, \\ Avenida Brasil 4365, 21040-900 Rio de Janeiro, RJ, Brasil \\ ${ }^{4}$ Institut de Recherche pour le Développment, Centre IRD d'Ile de France, \\ Avenue Henri Varagnat 32, Bondy cedex, 93143, France \\ ${ }^{5}$ Universidade Federal Fluminense, Instituto de Geociências, Laboratório de Geologia Marinha, \\ Avenida Litorânea s/n, 24210-340 Niterói, RJ, Brasil
}

Manuscript received on September 14, 2009; accepted for publication on January 1, 2011

\begin{abstract}
Historians claim that European colonizers of the northern coast of Rio de Janeiro State found vast herbaceous fields when arrived in this region. Hypotheses about the origin of these fields include forest burning by the Goitacás indians and periodical floods by the Paraíba do Sul River and the lagoon system. The palynologycal analysis of two lake cores obtained in the municipality of Campos dos Goytacazes revealed opening episodes of hygrophilous forest and the establishment of field vegetation, recorded at ca. 6,500 and ca. $4,000{ }^{14} \mathrm{C} \mathrm{yr} \mathrm{BP}$. The partial replacement of forest by field vegetation in the first episode was probably caused by floods of the lower areas during the development of the Holocene lagoon phase. During the second episode, successions of vegetational patterns occurred due to lowering of the sea level. Drying and enlarging of the coastal plain have allowed its colonization by herbs and heliophyte plants. The palynological analysis does not provide any evidence that sustains the theories of use of fire and agricultural activities by indigenous groups during these periods.
\end{abstract}

Key words: Brazil, Campos dos Goytacazes, Holocene, palynology, vegetation dynamics.

\section{INTRODUCTION}

The geological features of the sea level oscillation during the Holocene in the coastal/deltaic plain of the Paraíba do Sul River, northern region of Rio de Janeiro State, were investigated by Martin et al. (1984, 1993, 1997). This region presents several shallow lakes, actually isolated or not from the sea, being relict bays of a large palaeolagoon system. Several palaeoenvironmental and palynological studies have demonstrated that the sea

Correspondence to: Cynthia F.P. da Luz

E-mail: cyluz@yahoo.com.br level oscillation during the Holocene changed the configuration of the Brazilian coast in many sites. These significant events affected the sedimentation process in lakes, and the regional vegetation (Cordeiro and Lorscheitter 1994, Lorscheitter 1997, Coelho et al. 1999, 2002, 2008, Barth et al. 2001, 2004, 2006, Macedo et al. 2007). The Campos dos Goytacazes Municipality, located in the northern coast region of the state of Rio de Janeiro, is an important area for palaeoenvironmental studies. The Atlantic Forest in this region represents a mosaic of different ecosystems, as xeromor- 
phic beach ridges, "Restinga" vegetation, Tropical Seasonal Semideciduous forest, Evergreen Rainfall forest, hygrophilous/swampy vegetation and grassland. Despite its environmental importance, the economical activities developed in this region since the arrival of Europeans have destructed large areas of the original vegetation and of the lake/lagoon sediments.

With the aim of reconstructing the temporal dynamics of the vegetation during the last 7,000 years, correlated to climatic changes and the sea level oscillation, palynological studies were performed on one core obtained in the Lagoa de Cima lake and on another in the Lagoa do Campelo lake, both located in the lowlands of the municipality of Campos dos Goytacazes. Palynological studies of surface sediment samples were conducted to elucidate the modern processes that have influenced the sedimentation of palynomorphs inside these lakes (Luz et al. 2002, 2003, 2005, 2010). The investigation was established upon the data obtained from palynological analyses of sediments, considering the palynomorphs as pollen grains, spores of Pteridophyta and Bryophyta, zygospores and coenobia of Chloroccocales algae.

\section{STUdy Site}

The coastal plain of Campos dos Goytacazes Municipality presents a group of lakes/palaeolagoons isolated from the sea during the Quaternary by the Paraíba do Sul River sediments (Lagoa de Cima lake), and by sand barriers or beach ridges (Lagoa Salgada lake and Lagoa do Campelo lake) (Fig. 1). These continental Tertiary sediments were invaded by seawater during the Holocene transgression phases, giving rise to numerous palaeolagoons. Their development into lakes can be related to the sea level oscillation during the last 7,000 years. The initial phase was established at south of Cape São Tomé with the formation of a large palaeolagoon and an intralagoonal delta related to the Lagoa Feia lake formation, the largest lake in the region. The establishment of a beach ridge system originated many isolated lakes during this phase. The Paraíba do Sul River changed to its actual position probably during the last sea transgression, remaining numerous palaeochannels. Another beach ridge system was developed later at the northern side of this cape, originating an additional lake system (Martin et al. 1984, 1993, 1997).
The Lagoa de Cima lake is embedded in a valley (Imbé River basin) located between the Barreiras Formation and the bedrock, $50 \mathrm{~km}$ west from the coastal line at about $30 \mathrm{~m}$ high. This lake may have been formed by an obstruction of a palaeolagoon called Ururaí Bay, and, therefore, represents the oldest lake in this region. The water is fresh and presents a diatomite deposit at its margins. It is conditioned by the inflow of the rivers Urubu and Imbé, and presents an outlet called Ururaí that flows towards the Lagoa Feia lake. This last lake is connected to the sea by a narrow passage. Nowadays, its drainage basin occupies an area of circa $986 \mathrm{~km}^{2}$ and does not present industry activities, but an intense sugarcane agriculture, pastureland, and a small remnant fragment of the Atlantic forest bordering the lake (Soffiati Netto 1985, 1991, FEEMA 1993). The Evergreen Rainforest covers the high mountains of the drainage basin, especially inside the Parque Estadual do Desengano, a government area for protecting the forest that is located $5 \mathrm{~km}$ west from the Lagoa de Cima lake (RADAMBRASIL 1983).

The Lagoa do Campelo lake is located at $17 \mathrm{~km}$ west from the coastline, at about $8 \mathrm{~m}$ high, bordering the Barreiras Formation and coming in touch with the flattened sediments of the coastal plain, which cover the Cretaceous layers of the Campos Basin. Its drainage basin is not well limited and occupies an area of circa $98 \mathrm{~km}^{2}$. Without tributaries and effluents, the lake receives fresh water and sediments from several swamps and bogs connected to the Paraíba do Sul River. The water of the lake was not naturally drained into the Atlantic Ocean (Tolentino et al. 1986). Nevertheless, in 1950 the extinguished Departamento Nacional de Obras de Saneamento - DNOS (National Sanitation Department) undertook several drainage alterations in the Campos dos Goytacazes Municipality, in order to control the natural floods in this region. The construction of a channel connecting this lake to the Paraíba do Sul River and another channel towards the sea resulted in a negative hydrological balance (Soffiati Netto 1985, 1991, Bidegain 2002). A small remnant of the Seasonal Semideciduous forest can be observed at $5 \mathrm{~km}$ southwest of the lake, and a small swampy forest fragment of "Restinga" vegetation in the northeastern margin of the lake. Pastureland, sugar-cane agriculture and subsistence plantations constitute the regional landscape of 

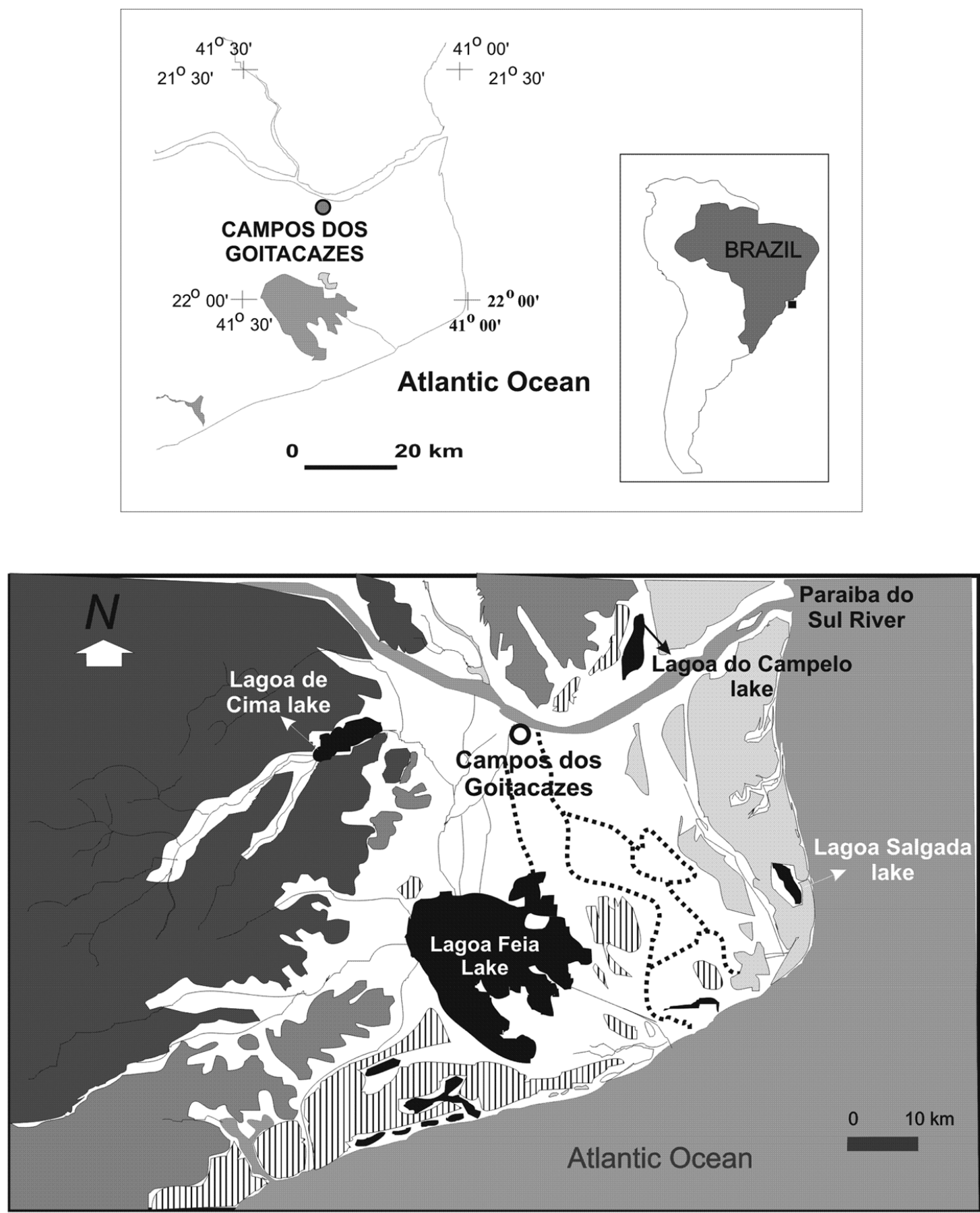

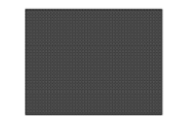

Pre-Cambrian Basement

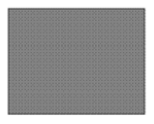

Barreira Formation (Tertiary)
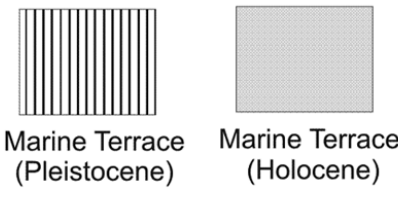

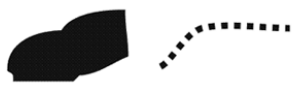

Lakes Paleochannels

Fig. 1 - Geological map of deltaic plain of the Paraiba do Sul River and location of the Lagoa de Cima and the Lagoa do Campelo lakes, Campos dos Goytacazes Municipality (Martin et al. 1993, modified). 
the drainage basin. The marsh vegetation next to the lake borders presents Cyperaceae, Poaceae, some additional plant taxa, and a characteristic large belt of cattail (Typha).

The studied region has a hot and humid climate with a strong seasonal influence. The rainfall pattern is related to a rainy summer with a dry season from May to September, during the winter, and with indices above $200 \mathrm{~mm}$ per month (AW of Koeppen). The average annual rainfall is around $900-1,100 \mathrm{~mm}$, and the mean annual temperature around $22^{\circ} \mathrm{C}$. The predominant wind comes from the NE (RADAMBRASIL 1983, Tolentino et al. 1986, FEEMA 1993, Bidegain 2002).

The anthropic influence in the northern region of the Rio de Janeiro State is intense and changed all the vegetation cover in the region. Assumpção and Nascimento (2000) conducted a floristic analysis of a few forest remnants of the "Restinga" vegetation in Grussaí (20 km southeast of the Lagoa do Campelo lake). The phytosociological structure of a Seasonal Semideciduous forest called "Mata do Carvão", the largest remnant fragment in this region located about $25 \mathrm{~km}$ north of the Lagoa do Campelo lake, was studied by Silva and Nascimento (2001). Moreno et al. (2003) performed the floristic analysis of the arboreal stratum at $50 \mathrm{~m}$ high in the Imbé Basin. Carauta and Rocha (1988) listed the vegetation composition in this region.

\section{MATERIALS AND METHODS}

The RJ93/1 core (410 cm long) was collected in the northeastern area of the Lagoa de Cima lake using a vibracore sampler presented in Martin et al. (1995). Several sedimentological sequences could be identified (Fig. 2). The following 23 levels from the Lagoa de Cima lake were analyzed: $02-03 \mathrm{~cm}, 12-13 \mathrm{~cm}, 22-$ $23 \mathrm{~cm}, 34-35 \mathrm{~cm}, 44-45 \mathrm{~cm}, 56-57 \mathrm{~cm}, 62-63 \mathrm{~cm}, 72-$ $73 \mathrm{~cm}, 83-84 \mathrm{~cm}, 92-93 \mathrm{~cm}, 102-103 \mathrm{~cm}, 112-113 \mathrm{~cm}$, $129-130 \mathrm{~cm}, 146-147 \mathrm{~cm}, 169-170 \mathrm{~cm}, 182-183 \mathrm{~cm}, 202-$ $203 \mathrm{~cm}, 212-213 \mathrm{~cm}, 222-223 \mathrm{~cm}, 232-233 \mathrm{~cm}, 242-$ $243 \mathrm{~cm}, 258-259 \mathrm{~cm}$ and 292-293 cm. Three samples were submitted to radiocarbon dating at Bondy Laboratories (Institut Français de Recherche Scientifique pour le Développment en Coopération, France) and one at Beta Analytic Inc (Florida, USA) (Table I).
The Campelo 2001 core (205 cm long) was taken with a percussion sampler at the central part of the Lagoa do Campelo lake. From the base to the top of the core, several sequences were identified (Fig. 3). Six levels from the Lagoa do Campelo lake were analyzed: $20-21 \mathrm{~cm}, 98-99 \mathrm{~cm}, 193-194 \mathrm{~cm}, 200-201 \mathrm{~cm}$, 203-204 cm and 204-205 cm. Two samples of this core were submitted to radiocarbon dating by Beta Analytic Inc. (Florida, USA) (Table II).

The $4 \mathrm{~cm}^{3}$ of sediments from each level were prepared using the standard procedure (Ybert et al. 1992). More than 500 pollen grains of each level, besides the introduced Lycopodium clavatum L. spores, were counted. The concentration of palynomorphs was plotted considering the number of marker spores per $\mathrm{cm}^{3}$ of sediment (Stockmarr 1971). TILIA software was used for statistical treatment of the palynological data. Pollen percentages were calculated based on the total pollen sum, excluding the pollen grains from hidrophyte/swampy plants (Typhaceae, Cyperaceae, Onagraceae, Scrophulariaceae, Utricullaria, Eicchornia, Nymphaceae and Sagittaria). The diagrams comprised all pollen grains that were grouped according to their plant habitat types: arboreal (shrubs and trees), nonarboreal (herbs and herbs/shrubs), other (all variable habitus) and hidrophytes, apart from fern spores, bryophytae spores and algae.

\section{RESULTS}

At the Lagoa de Cima lake the sandy base sediments, from 410 up to $292 \mathrm{~cm}$, were devoid of palynomorphs (Fig. 4). In sequence, four main zones could be defined based on chronology and palynomorph assemblages (Table I).

ZONE 1 (292 UP TO $171 \mathrm{CM}$, A CLAY-SANDY SEQUENCE CORRESPONDING TO AN EARLY PERIOD OF $6,985 \pm 50$ YR BP UNTIL CIRCA 5,725 YR BP - INTERPOLATED AGE)

The first analyzed sediment sample was from the 292/ $293 \mathrm{~cm}$ level. All pollen grains and spores were broken, degraded or corroded, and palynomorphs concentration was very low. It increased gradually in this zone until sample $212 / 213 \mathrm{~cm}$ (418962 palynomorphs $/ \mathrm{cm}^{3}$, the highest concentration in the whole core), falling abruptly down in the $202 / 203 \mathrm{~cm}$ sample (8228 palyno- 
(uэ) чұdәव

일
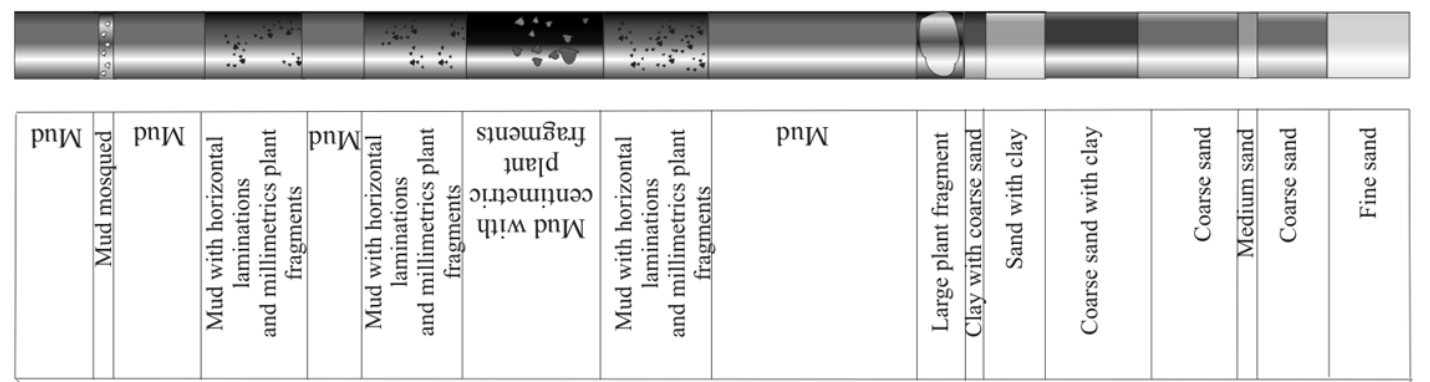

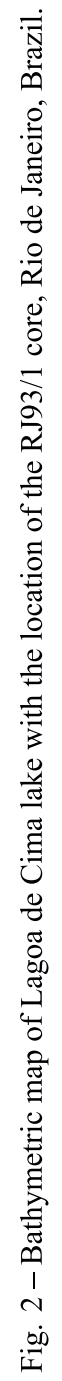


TABLE I

Radiocarbon dates of Quaternary sediments at four levels of the core RJ93/1 from the Lagoa de Cima lake, Campos dos Goytacazes Municipality, Rio de Janeiro, Brazil.

\begin{tabular}{c|c|c|c|c}
\hline $\begin{array}{c}\text { Reference code } \\
\text { from Bondy } \\
\text { Laboratories and } \\
\text { Beta Analytic Inc. }\end{array}$ & $\begin{array}{c}\text { Conventional } \\
\text { radiocarbon } \\
\text { age }\end{array}$ & $\begin{array}{c}\text { Calibrated } \\
\text { radiocarbon } \\
\text { age }\end{array}$ & $\begin{array}{c}\text { Depth of } \\
\text { the samples }\end{array}$ & Material \\
\hline LY-10214 & $6,985 \pm 50 \mathrm{BP}$ & $\begin{array}{c}\text { Cal BP 7,930 } \\
\text { to 7,690 }\end{array}$ & $260-272 \mathrm{~cm}$ & Wood fragment \\
\hline LY-10213 & $6,880 \pm 65 \mathrm{BP}$ & $\begin{array}{c}\text { Cal BP 7,795 } \\
\text { to 7,605 }\end{array}$ & $234-240 \mathrm{~cm}$ & Mud \\
\hline LY-10310 & $6,225 \pm 50 \mathrm{BP}$ & $\begin{array}{c}\text { Cal BP 7,510 } \\
\text { to 7,320 }\end{array}$ & $190-194 \mathrm{~cm}$ & Organic Mud \\
\hline Beta-170237 & $3,220 \pm 40 \mathrm{BP}$ & $\begin{array}{c}\text { Cal BP } 3,490 \\
\text { to 3,360 }\end{array}$ & $23-28 \mathrm{~cm}$ & Mud \\
\hline
\end{tabular}

TABLE II

Radiocarbon dates of Quaternary sediments at two levels of the core Campelo 2001 from the Lagoa do Campelo lake, Campos dos Goytacazes Municipality, Rio de Janeiro, Brazil.

\begin{tabular}{c|c|c|c|c}
\hline $\begin{array}{c}\text { Reference code } \\
\text { from Beta } \\
\text { Analytic Inc. }\end{array}$ & $\begin{array}{c}\text { Conventional } \\
\text { radiocarbon } \\
\text { age }\end{array}$ & $\begin{array}{c}\text { Calibrated } \\
\text { radiocarbon } \\
\text { age }\end{array}$ & $\begin{array}{c}\text { Depth of } \\
\text { the samples }\end{array}$ & Material \\
\hline Beta-157950 & $2,790 \pm 40 \mathrm{BP}$ & $\begin{array}{c}\text { Cal BP } 2,970 \\
\text { to } 2,780\end{array}$ & $204-205 \mathrm{~cm}$ & Peat \\
\hline Beta-157947 & $2,320 \pm 80 \mathrm{BP}$ & $\begin{array}{c}\text { Cal BP } 2,500 \\
\text { to } 2,140\end{array}$ & $16-23 \mathrm{~cm}$ & Peat \\
\hline
\end{tabular}

morphs $/ \mathrm{cm}^{3}$ ), and slightly increased again up to the $182 / 183 \mathrm{~cm}$ sample, the top of the rich mud sequence. Neither arboreal pollen grains nor algae were detected. The deposition of a vegetal remain dated from 6,985 \pm 50 yr BP caused a perturbation in the clay sedimentation. Cyperaceae pollen grains were only observed in low percentage and concentration regarding the hidrophytes, as well as Poaceae of the herbs, and Moraceae of variable habitus plants. The highest concentration of palynomorphs was observed in sample 212/ $213 \mathrm{~cm}$, presenting hidrophyte (mostly Cyperaceae and Typhaceae), herbs (Althernanthera and Poaceae), variable habitus plant (Mimosa pudica presenting 59\% and Moraceae $4,7 \%$ of the pollen sum), shrub (Piper and Geonoma) and arboreal/shrub (Cecropia of 5,6\% and Myrcia of 1,9\%) pollen grains. Fern spores comprised about $25 \%$ of palynomorphs counted. Bryophyta spores showed in the 242/243 level their second largest concentration value in the core. Of the algae in this zone, Botryococcus disappeared after the 212/213 cm level, Spyrogira was only observed in the samples 212/ $213 \mathrm{~cm}$ and 182/183 cm, and Pseudoschizea was seen in sample $182 / 183 \mathrm{~cm}$ only presenting its highest concentration in the core.

ZONE 2 (170-131 CM, A MUD SEQUENCE CORRESPONDING TO THE INTERVAL FROM 5,725 YR BP - INTERPOLATED AGE - UNTIL CA. 4,925 YR BP - INTERPOLATED AGE)

The tendency of low palynomorph concentration was maintained, and the majority of pollen and spores has damaged exines. The arboreal pollen types prevailed over the non-arboreal. The hidrophytes were well represented by Cyperaceae. Arboreal/shrub pollen types of Alchornea, Cecropia, Myrtaceae and Piptadenia, as well as Trema (arboreal), Piper (shrubs), Araceae and Poaceae (herbs) and Moraceae (variable habitus) 


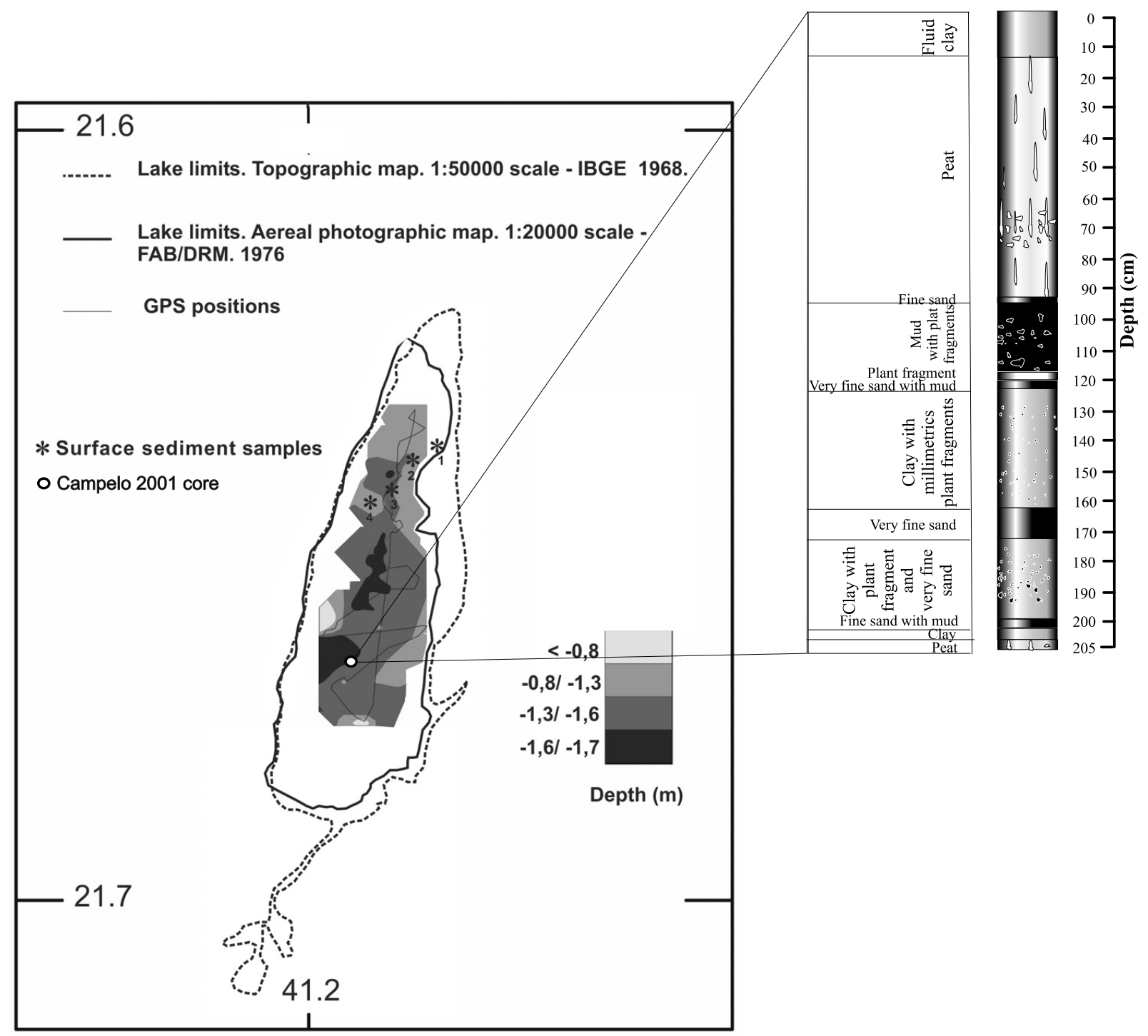

Fig. 3 - Bathymetric map of Lagoa do Campelo lake with the location of the Campelo 2001 core, Rio de Janeiro, Brazil (Luz et al. 2005, modified).

predominated. Herbs/shrubs were only represented by Tetrapteris. Fern spores were uncommon. Spyrogira was only seen among the algae.

ZONE 3 (130-11 CM, A MUD SEQUENCE CORRESPONDING TO THE INTERVAL FROM 4,925 YR BP - INTERPOLATED AGE - UNTIL CA. 3,000 YR BP)

Pollen and spores were well preserved at the beginning of this zone only. In the basal level of this zone (rich in vegetable remains) occurred a gradual increase in the concentration of hidrophytes and arboreal pollen types. The arboreal pollen types latter gradually decreased from the $112 / 113 \mathrm{~cm}$ level to the top of this zone due to the over-representation of Mimosa pudica (more than $70 \%$ of the pollen sum). However, the concentration values grew up gradually mostly because of Anadenanthera, Celtis and Trema arboreal pollen types. Serjania was detected. Arboreal/shrub pollen types of Alchornea, Arecaceae, Cecropia, Ficus, Myrtaceae and Piptadenia predominated. Piper presented high concentration. Althernanthera, Apiaceae, Araceae, Borreria, Gomphrena and Poaceae were observed among herbaceous pollen types. Ichthyothere/ Aspilia, Phyllanthus and Tetrapteris prevailed among herbs/shrubs. Asteraceae, Melastomataceae/Combretaceae, Monocotyledonous, Moraceae, Psycothria, sev- 


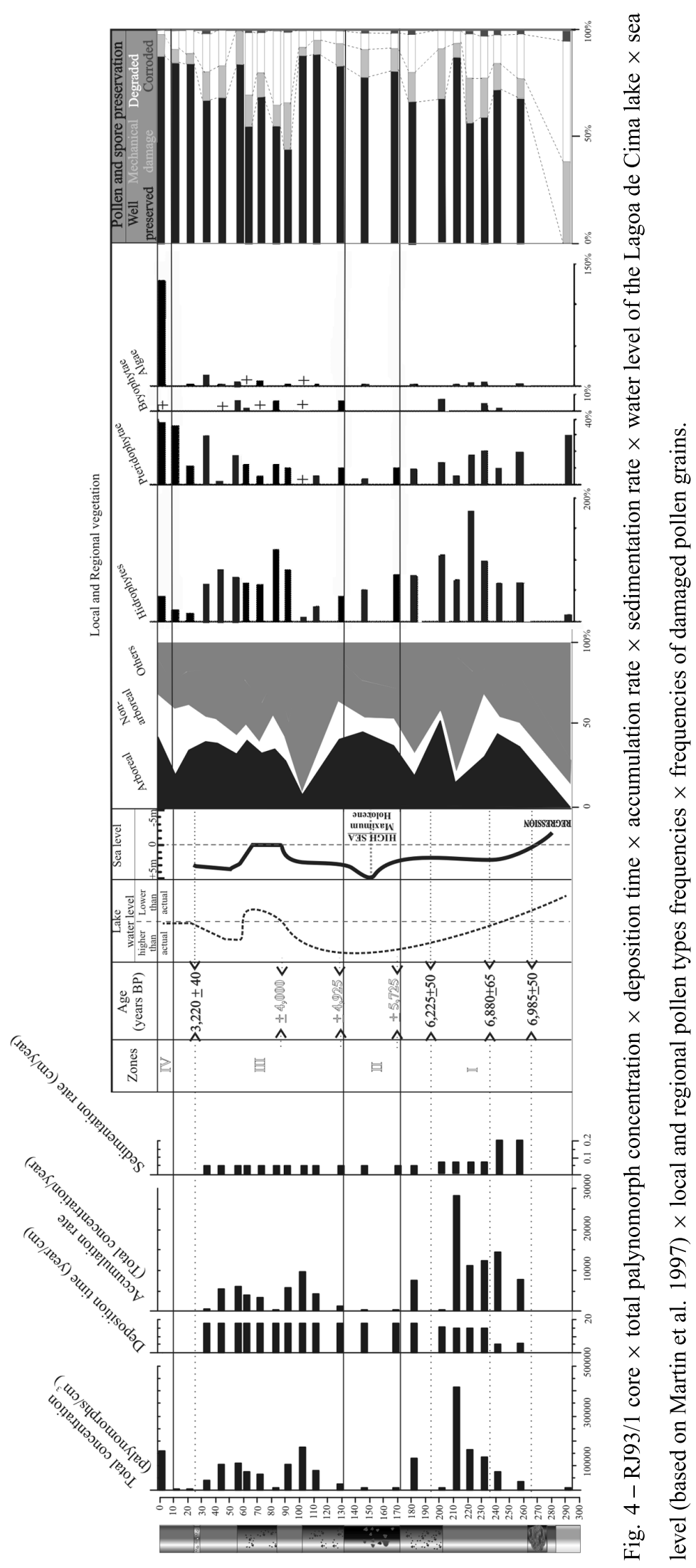


eral Fabaceae, Rubiaceae, Solanaceae and Mimosa pudica prevailed among the variable habitus category.

From the 92/93 cm level (without visible vegetal remains) to the $62 / 63 \mathrm{~cm}$ level (a new organic interval) occurred an increase of degraded palynomorphs and arboreal types. The sample 92/93 cm presented the second largest values of arboreal pollen concentration in the core (4873 pollen grains $/ \mathrm{cm}^{3}$ ), mostly due to Anadenanthera, Celtis, Platymiscium and Trema. Alchornea, Erythroxylum, Ilex, Lamanonia, Myrtaceae, Olacaceae, Ouratea, Piptadenia, Rapanea, Vochysia, Weinmannia and Zanthoxylum prevailed among the arboreal/shrubs pollen types. Piper and Struthanthus were present. Asteraceae, Melastomataceae, Moraceae, Fabaceae and Rubiaceae prevailed in the variable habitus category. Cyperaceae predominated among hidrophytes. Araceae and Poaceae were observed among the herbs. Fern spores of Selaginella, Pseudoschizaea and Spyrogira were observed among the algae.

In the $56 / 57 \mathrm{~cm}$ level (rich in vegetal remains), the percentage of well-preserved pollen grains and fern spores was high, prevailing the arboreal pollen types. Podocarpus pollen grains were observed only in this sample. Fern and Bryophytae spores presented their highest concentration in the core. Cosmarium and Spyrogira were observed.

ZONE 4 (11 CM UNTIL THE TOP OF THE CORE, A MUD SEQUENCE)

This zone included only the $02 / 03 \mathrm{~cm}$ level analyzed. Pollen and spores showed well-preserved sporoderms, and a richness of pollen types occurs. Palynomorphs concentration increased, and arboreal pollen grains (21826 pollen grains $/ \mathrm{cm}^{3}$ ) predominated over the nonarboreal (13997 pollen grains $\left./ \mathrm{cm}^{3}\right)$. Fern spores comprised about $40 \%$ of the palynomorphs and presented their highest concentration in the core. The algae predominated among the palynomorphs and reached their maximum values in the core (mostly Spyrogira, Scenedesmus, Pediastrum, Mougeotia and Coelastrum).

At the Lagoa do Campelo lake core the chronology embraces a period of nearly 500 years, from circa 2,800 yr BP to 2,300 yr BP (Fig. 5, Table II). It reflects the change of vegetation and environment in the region.

The basal peat sequence, dated from circa 2,790 yr
BP, showed a great richness of palynomorphs, with the predominance of arboreal over the non-arboreal, herbs and hidrophyte pollen types. The percentages of corroded and degraded pollen grains and of palynomorph concentration were high. Pseudoschizaea was frequent.

The richness and concentration of palynomorphs strongly decreased in the posterior clay sequence in sample 203/204 cm. Exine degradation and corrosion were soft, but mechanical damages increased. The arboreal and non-arboreal pollen types were of similar percentages. Hidrophyte pollen and fern spores predominated.

The following mud-sand layer (sample 200/201 cm) showed no palynomorphs.

The palynomorph concentration decline progressively in the following clay layer of sample 193/194 cm. Preservation of palynomorphs showed a high percentage of broken and corroded pollen grains and fern spores. The arboreal pollen types presented a slight dominance over the non-arboreal, with higher values of Inga, Cecropia and Piper. Hidrophytes and fern spores also prevailed. No algae were observed.

In the sample 98/99 cm (a mud layer) the concentration of palynomorphs remained low. The percentage of degraded palynomorphs increased, the corroded and mechanical damaged decreased. The arboreal predominated over the non-arboreal pollen types. For the first time in the core, Mougeotia zigospores were observed.

A sample near the top of the core $(20 / 21 \mathrm{~cm}$ sample) demonstrated a great richness of pollen types and a high concentration of palynomorphs. Non-arboreal pollen types increased. Not corroded pollen grains and fern spores were observed, although the percentage of the degraded ones remained high.

\section{DISCUSSION}

The composition and accumulation of palynomorph assemblages in the sediments of Lagoa de Cima and Lagoa do Campelo lakes changed since the Mid-Holocene due to several factors as follows (Figs. 4 and 5).

The analysis of the RJ93/1 core from the Lagoa de Cima lake can corroborate the results of Martin et al (1997), i.e. that the sea level before 7,000 yr BP $\left({ }^{14} \mathrm{C}\right.$ age) was probably lower than the current sea level, which was demonstrated by a sandy sequence in the 


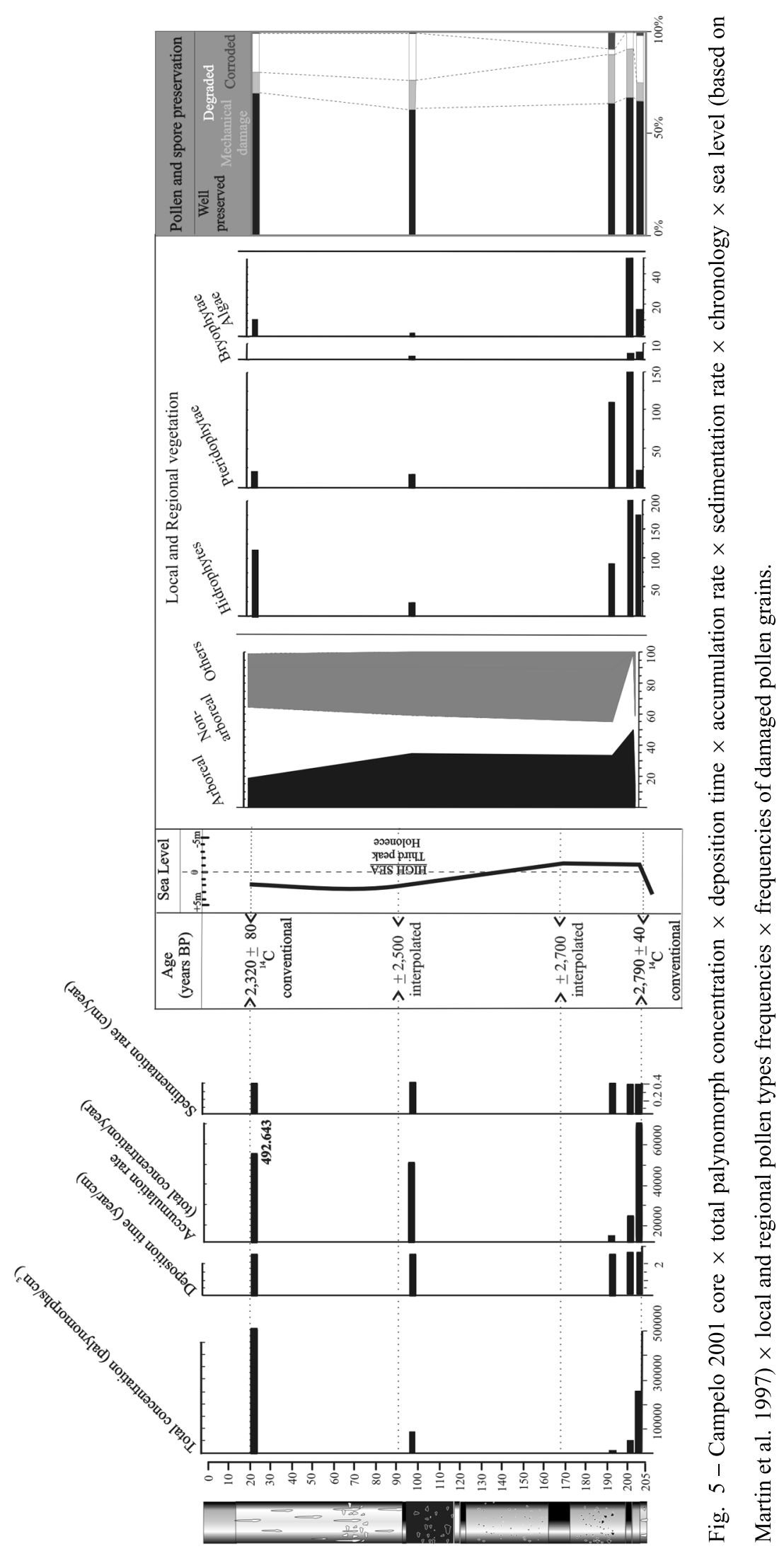


lower part of the core and very low palynomorph concentrations. This can indicate that the waterflow velocity in the Lagoa de Cima lake increased due to falling sea level, resulting in transport of sediments of coarser particles to the drilling place and a palynomorph deposition downstream. A sandy-clay interval covered this sandy sequence and provided an evidence of a transitional phase between a continental deposition (probably fluvial) and a muddy sequence of lake sediments. The paleogeographic reconstruction of the coastal plain of the Paraíba do Sul River (Martin et al. 1984, 1993, 1997) showed that the Holocene sedimentation started with the formation of a barrier-island/lagoon system. The sediments transported by the Paraíba do Sul River began to be deposited into this lagoon, starting the construction of an intralagoonal delta. With the gradual elevation of the sea level, the delta sediments were deposited gradually at higher altitudes, damming the valley of the Imbé River. Pollen grain deposition of hydrophylous plants increased in the place of core drilling. The hygrophilous forest settled around the lake since its origin and co-inhabited at around 6,500 years BP with grassland vegetation. The flooded areas spread through the low valley of the Imbé River during the maximum of the Holocene sea level $( \pm 5,100 \mathrm{yr}$ BP $)$, and large hygrophilous forests developed. Around 4,000 yr BP, the sudden lowering of the sea level caused the downfall of the accumulation values of palynomorphs in the drilling place, indicating again their preferential deposition away from the outlet side of the lake. The grassland vegetation developed again at this time and co-inhabited with the hygrophilous forest. The second lagoon phase started at circa 4,000 yr BP and facilitated the development of the hygrophilous forests. The rate of sedimentation in the drilling place was very low after 3,000 $\mathrm{yr}$ BP probably because of the removal of fine sediments due to the increasing flow of the Ururaí River towards to Lagoa Feia lake. The hydraulic activities performed by the Brazilian Government in the region may be also responsible for this occurrence. The sample of the top of the core probably corresponds to the actual sedimentation in the lake and presents pollen types of plants actually cultivated in the region.

Luz et al. (1999) established four main biostratigraphic zones based on the palynological analysis of another core (RJ92/6) also collected in the Lagoa de
Cima lake. The results obtained were incomplete due to a clear inversion of sediments in this core demonstrated by radiocarbon dates, as a consequence of deposition of a sandy barrier in the core, taking away the previous stratigraphic sequence and influencing the interpretations.

The sediments of the core Campelo 2001 from the Lagoa do Campelo lake comprised a period of 500 years of sedimentation, and their base corresponded to $\pm 2,800 \mathrm{yr}$ BP $\left({ }^{14} \mathrm{C}\right.$ age $)$. The palynological analysis reflected a well-represented hydrophytic vegetation of low richness of pollen types and high deposition of Pseudoschizaea in its basal sediments, characterizing the development of a swampy environment and a low water level. This time corresponded to a lowering of the sea level and originated a protrusion of the Paraíba do Sul River mouth into the ocean. The sea level remained low during circa 100 years, and the deposition of palynomorphs occurred away at the outlet side of the drilling point. Several swamps connected to the Paraíba do Sul River supplied the lake, but the water flowed into the channels of adjacent plains, carrying the fine sediments. With the rise of the sea level since 2,700 yr BP, the erosion in the outlet of the Paraíba do Sul River and the progressive damming of waters in the plain ocurred. Next to the positive eustatic peak (in about 2,500 yr BP), the pollen deposition was facilitated by the increase of the water level of the lake. At this time, the representation of pollen types from pioneer plants was high, and the richness of forest types increased. About 2,300 yr BP, the rate of total accumulation of palynomorphs was very high mainly by the increase of herbs and hydrophilous pollen types. The rate of sedimentation was very low after 2,300 yr BP (Luz et al. 2006).

\section{CONCLUSION}

Periods of the establishment of herbaceous areas replacing the hygrophilous forest during the Holocene in the northern Rio de Janeiro State were probably due to a natural changing process related to sea level oscillations, which reflected sometimes in the damming of the Paraíba do Sul River and sometimes in the draining of the plain. These environmental variations prevented the establishment of continuous arboreal and shrub vegetation, causing the fragmentation of the forest or even the 
substitution of the forest by a vast field vegetation into the landscape.

Evidences of the use of fire and the presence of pollen grains of cultivated plants by indigenous groups were not observed in the sediments of these lakes during the studied period.

\section{ACKNOWLEDGMENTS}

To the Conselho Nacional de Desenvolvimento Científico e Tecnológico (CNPq) for a doctoral scholarship to the first autor. To the Fundação Carlos Chagas Filho de Amparo à Pesquisa do Estado do Rio de Janeiro (FAPERJ) and WWF (World Wild Foundation) for financial support. Many thanks to Dr. Luciane Guimarães Coelho for collaboration with Tilia Graph computer program and to Dr. Leonardo Borghi for cooperation with the sedimentological description of the core RJ93/1.

\section{RESUMO}

Os historiadores citam que os europeus colonizadores da costa norte do Estado do Rio de Janeiro encontraram vastos campos herbáceos quando chegaram a essa região. As hipóteses sobre a origem desses campos incluem aplicação de "queimada" pelos índios Goitacás e periódicas inundações do rio Paraíba do Sul e sistemas lagunares. A análise palinológica de dois testemunhos de sondagem obtidos no município de Campos dos Goytacazes revelou epsódios de abertura da floresta higrófila e o estabelecimento da vegetação campestre, datados em ca. 6.500 e $4.000{ }^{14} \mathrm{C}$ anos AP. O primeiro epsódio de substituição parcial da floresta pela vegetação campestre se deu provavelmente pelas inundações das áreas baixas durante o desenvolvimento da fase lagunar holocênica. No segundo epsódio, os padrões de sucessão da vegetação ocorreram como consequência do abaixamento do nível do mar. O ressecamento e a progressão da planície costeira permitiram sua colonização pelas plantas herbáceas heliófitas. A análise palinológica não forneceu qualquer evidência que apoie as teorias do uso do fogo e da prática de atividades agrícolas por grupos indígenas durante esses períodos.

Palavras-chave: Brasil, Campos dos Goytacazes, Holoceno, palinologia, dinâmica da vegetação.

\section{REFERENCES}

AsSumpÇÃo J AND NASCIMENTO MT. 2000. Estrutura e composição florística de 4 formações vegetais de restinga no complexo lagunar Grussaí/Iquipari, São João da Barra, Rio de Janeiro, Brasil. Acta Bot Bras 14: 301-315.

Barth OM, Barreto CF, Coelho LG AND Luz CFP. 2004. Pollen record and paleoenvironment of a 4210 years BP old sediment in the Bay of Guanabara, Rio de Janeiro, Brazil. An Acad Bras Cienc 76: 549-551.

BARTH OM, LUz CFP, TOLEDo MB, BARRos MA AND SILVA CG. 2001. Palynological data from Quaternary deposits of two lakes in the northern region of the state of Rio de Janeiro. In: GOODMAN DK AND CLARKE RT (Eds), Proceedings of the IX International Palynological Congress, Houston, Texas, USA, 1996, American Association of Stratigraphic Palynologists Foundation, p. 443-450.

BARTh OM, SÃo-Thiago LEU AND BARros MA. 2006. Paleoenvironment interpretation of a 1760 years BP old sediment in a mangrove area of the Bay of guanabara, using pollen analysis. An Acad Bras Cienc 78: 227-229.

Bidegain P. 2002. Lagoas do Norte Fluminense - Perfil Ambiental. Rio de Janeiro: Semads, 148 p.

CARAUTA JPP AND Rocha ESF. 1988. Conservação da flora do trecho fluminense da bacia hidrográfica do rio Paraíba do Sul. Albertoa 11: 86-135.

Coelho LG, Barth OM and Araujo DSD. 2008. Pollen analysis of Holocene sediments from the Poço das Antas National Biological Reserve, Silva Jardim, Rio de Janeiro, Brazil. An Acad Bras Cienc 80: 531-541.

Coelho LG, Barth OM and Chaves HAF. 1999. O registro palinológico das mudanças da vegetação na região da Baía de Sepetiba, Rio de Janeiro, nos últimos 1000 anos. Leandra 14: 51-63.

Coelho LG, Barth OM And Chaves HAF. 2002. Palynological records of environmental changes in Guaratiba mangrove area, Southeast Brazil, in the last 6000 years BP. Pesqui Geocienc 29: 71-79.

Cordeiro SH AND LorscheitTer ML. 1994. Palynology of Lagoa dos Patos sediments, Rio Grande do Sul, Brazil. J Paleolimnol 10: 35-42.

DRM - DEPARTAMENTO DE RECURSOS MineRAis DO RIO DE JANEIRO. 1976. Fotografias aéreas do sobrevôo realizado pela Força Aérea Brasileira (FAB), litoral norte Fluminense. Escala; 1:20.000.

FEEMA - FundaÇÃo Estadual DE Engenharia do Meio Ambiente. 1993. Perfil ambiental do município de Campos. Rio de Janeiro, 146 p.

Instituto Brasileiro DE Geografia e Estatística. 1968. Carta topográfica do IBGE, escala 1:50.000, Folha São João da Barra. 
LorscheitTer ML. 1997. Paleoambientes do sul do Brasil no Quaternário através da Palinologia: revisão dos resultados obtidos. Rev Ung Geocienc Ano II, número especial, p. 197-199.

LUZ CFP, BARTH OM AND MARTIN L. 1999. Evolução das florestas Tropical Estacional e Ombrófila Densa durante o holoceno médio na região norte do Rio de Janeiro, baseada em palinologia. Rev Ung Geocienc 4: 74-84.

LUZ CFP, BARTH OM AND SILVA CG. 2005. Spatial distribution of palynomorphs in the surface sediments of the Lagoa do Campelo lake, north region of Rio de Janeiro state, Brazil. Acta Bot Bras 19: 741-752.

Luz CFP, BARTh OM AND SILVA CG. 2006. Dinâmica temporal na Lagoa do Campelo, região norte do estado do Rio de Janeiro, baseada em estudos palinológicos. Rev Bras Paleont 9: 127-136.

LUZ CFP, BARTH OM AND SILVA CG. 2010. Modern processes of palynomorph deposition at lakes of the northern region of the Rio de Janeiro State, Brazil. An Acad Bras Cienc 82: 679-690.

Luz CFP, BARth OM, Silva CG AND Nogueira IS. 2003. Dinâmica espacial na deposição de pólen e esporos de Pteridófitas e Briófitas nos sedimentos da superfície de fundo da Lagoa de Cima, município de Campos do Goytacazes, Rio de Janeiro, Brasil. In: IX Congresso da Associação Brasileira de Estudos do Quaternário, Recife, Pernambuco. CD-rom artigo 54.

Luz CFP, Nogueira IS, BARTh OM AND Silva CG. 2002. Differential sedimentation of algae Chlorococcales (Scenedesmus, Coelastrum and Pediastrum) in Lagoa de Cima, Campos dos Goytacazes municipality (Rio de Janeiro, Brazil). Pesqui Geocienc 29: 65-75.

Macedo RB, Cancelli RR, Bauermann SG, BorDignon SAL AND Neves PCP. 2007. Palinologia de níveis do Holoceno da Planície Costeira do Rio Grande do Sul (localidade de Passinhos), Brasil. Gaea 3: 68-74.

MARTIN L, BITTENCOURT ACSP, FLEXOR JM AND VILAS-BOAS GS. 1984. Enregistrement de périodes de fortes et faibles énergies à l'embouchure d'un fleuve. Le cas du Paraíba do Sul (Brésil). Implications paléoclimatiques. Comptes Rendus - Academie des Sciences, Ser II 299: 661-664.

Martin L, FleXor JM AND Suguio K. 1995. Vibrotestemunhador leve: construção, utilização e potencialidades. Rev IG São Paulo 16: 59-66.
Martin L, Suguio K, Dominguez JML and Flexor JM. 1997. Geologia do Quaternário costeiro do litoral norte do Rio de Janeiro e do Espírito Santo. Publicação CPRM (Serviço Geológico do Brasil) \& FAPES (Texto explicativo, 2 folhas coloridas na escala do 1/250 000 . Folha do Espírito Santo e Folha do Norte do Estado do Rio), 104 p.

Martin L, Suguio K And FleXor JM. 1993. As flutuações do nível do mar durante o Quaternário Superior e a evolução geológica de "deltas" brasileiros. Boletim IG USP 15: 186. (publ. especial).

Moreno Mr, Nascimento MT And Kurtz BC. 2003. Estrutura e composição florística do estrato arbóreo em duas zonas altitudinais diferentes em mata Atlântica de encosta na região do Imbé, RJ. Acta Bot Bras 17: 371386.

RADAMBRASIL. 1983. Levantamento de recursos naturais, Geologia, Geomorfologia, Pedologia, Vegetação. Uso Potencial da Terra (Folhas SF 23/24 - RJ - Vitória). Publicação do Ministério das Minas e Energia, v. 32.

Silva GC AND NAscimento MT. 2001. Fitossociologia de um remanescente de mata sobre tabuleiros do norte do estado do Rio de Janeiro (mata do Carvão). Rev Bras Bot 24: $51-62$.

Soffiati Netto AA. 1985. A agonia das lagoas do Norte Fluminense. Cienc Cult 37: 1627-1638.

Soffiati Netto AA. 1991. Diagnóstico ambiental da região Norte-Noroeste fluminense. Rio de Janeiro, Relatório do Centro Norte Fluminense para a Conservação da Natureza, $28 \mathrm{p}$.

STOCKMARR J. 1971. Tablets with spores used in absolute pollen analysis. Pollen et Spores 13: 615-621.

Tolentino M, Esteves FA, Roland F And Thomaz SM. 1986. Composição química do sedimento de 12 lagoas do litoral fluminense e sua utilização na tipologia destes ecossistemas. Acta Limnol Bras 1: 431-447.

YBERT JP, SALGADO-LABOURIAU ML, BARTH OM, LorscheitTer ML, Barros MA, ChaVes SAM, LuZ CFP, Ribeiro MB, SCHEEL R AND ViCENTINI KF. 1992. Sugestões para padronização da metodologia empregada em estudos palinológicos do Quaternário. Rev IG São Paulo 13: 47-49. 